\title{
Twin Deficit Hypothesis: A Case of Pakistan
}

\author{
Farrah Yasmin* \\ The Women University, Multan Pakistan
}

\begin{abstract}
:
The prime motive of this study is to scrutinize the twin deficit for annual time series data over the period 1990-2010 for Pakistan. Twin deficit hypothesis expressed that an expansion in budget deficit will ground for rise in current account deficit. To diagnose affiliation amongst couple of variables, applied Unit root test (ADF-test), Johansen cointegration technique, Impulse response function and Granger causality test. The Granger causality demonstrate that the causality direction travel from current account deficit to budget deficit. When current account deficit occurs it leads to budget deficit. So the finding proves that there is a positive connection among both variables. Investigations are most reliable for Pakistan economy. Finally, this study confirms the rapport amid current account deficit and budget deficit.
\end{abstract}

Keywords: Budget deficit, Current account deficit, Pakistan

*Email: farraheconomist@gmail.com 


\section{Introduction}

The problem of twin deficit hypothesis was explored in 1980's for first time. At that time there was a record existence of deficit in current accounts along with the budgetary account deficit in the United States economy. Both the budgetary and current account deficit demonstrate that an extension in fiscal deficit direct to a balanced augment in deficit of current account. Similar problem is seen in USA (Normandin, 1999; Mann, 2002), similarly, Germany and Sweden faced the twin deficit problem in early 1990s (Ibrahim and Kumah, 1996) and Edwards, 2001) Similarly the results can vary even by using different models specification and econometric techniques for the data of a same country. Economic literature shows the budget deficit is a big problem for economy of both developed and developing states. It increases from 5.4 to 8.7 percent the previous both decades. In accordance with further arguments, there is an increase in current account deficit from 2.7 to 7.2 percent in the similar time period in Pakistan ${ }^{1}$. Most importantly, changes in fiscal deficit lead to a predictable development in current account balances, this issue is controversial. The significant aspect of this problem is named as twin deficit hypothesis. Current account deficit and budget deficit are interrelated and emerged together. Due to this, the emerging budget deficit The both deficits are an emerging topic and basic reason for all economic diseases of developing economies generally and particularly in Pakistan. So it is significant to quantify the rapport stuck between hypotheses of twin deficits. This study particularly focuses with reference to Pakistan economy.

Financial system of Pakistan is facing a stern dilemma of twin deficits because imports of Pakistan are continuously increasing especially the group of petroleum product moves a new higher imports bill which would affect the budget deficit badly. Over the period of 1991-2000 trade terms of Pakistan were normal, but after 2000 these terms reduced to an alarming sign (federal bureau of statistics). Since, economic scholars are trying to determine either current account will be rebalanced or not in coming decade. In the era of present globalization it is too important rapid growing and big democratic economy like as Pakistan should be aware by any increasing crises of balance of payments. However it is most important to understand the association amid deficit of current account and budget balance deficit for effectual policy implementation. So the prime objectives of the study are to find the systematic relationship between both of deficits (budgetary and current account deficits) and to check the causality direction and long run link among both deficits.

Second section is based on literature review. Section three presents theoretical grounds of twin deficits which are discussed in detail. Fourth section describes data methodology and empirical findings through using different statistical and econometric techniques. While in the last section concluding remarks and also policy implications are expressed.

\section{Literature Review}

(Mukhtar et al 2007); analysed twin deficit hypothesis by using quarterly time series data over the period 1975:1-2005:4 for Pakistan. He applied co integration test, error correlation model

${ }^{1}$ See Economic Survey of Pakistan 1992-2008

SIJMB $\quad P$ - ISSN: 2313-1217 E-ISSN: 2410-1885 @ 2015 Sukkur Institute of Business Administration V.2, No.1 | Apr 15 
(ECM), and Granger causality analysis and concluded that there exist bi-directional connection amongst these two variables.

(Bagheri et al 2012); estimated the twin deficit in Iran economy by using annual data ranging from 1971-2007, taking deficit and current accounts deficit as dependent and independent variables respectively. They used SUR regression and Granger causality test and investigated the existence of long run equilibrium connection amongst twin deficits.

(Lam 2012); adopted the unit root investigation, vector error correlation model, Granger causality-Wald test and Johansen co integration techniques and used time series data over period 1990-2011. The results revealed that in Vietnam economy connection holds among two deficits in a long run time period.

(Merza et al April, 2012); analysed the relationship between two variables by applying the quarterly data consisting the period 1993:4-2010:4. Impulses response function and Granger Causality test confirms that there is no existence of both deficits in Kuwait economy.

(Zamanzadeh and Mehrara 2011); confirmed the liaison among twin deficit in Iranian economy during the period 1959-2007 through application of vector error correlation model and co integration analysis. They found so as to the subsistence of optimistic affiliation among non-oil two deficits, and also the Granger causality analysis exhibit deficit of budget account balance and current account balance granger cause to each other.

(Yanik 2006); investigated the twin deficit hypothesis for Turkey while using quarterly data from 1988:1-2005:2 periods by applying Granger causality test and VAR model, and concluded that budget deficit and current account deficit move simultaneously in long run.

(Waliullah et al 2010); analysed the determinants of budget deficit and trade deficit on secondary data over the period 1970-2005, taking trade balance as dependent variable and income (GDP) as independent variable. They applied the bound testing approach of co integration, established autoregressive distributed lag frame work and error correction model. Their obtained results exhibited the existence of link among trade account balances and budget deficit.

(Azgun and Ozdemir 2008); adopted Johansen cointegration technique and Engle Granger causality analysis by using quarterly time series data over the period of 1980:1-2004:2. Their adopted variables were budget deficit and current account deficit in case of Pakistan economy. The results exhibited the link between budget deficit and current account deficit. (Vyshnyak 2000); employed Cointegration technique and Granger causality test to enquire the causality amongst variables in Ukraine economy taking quarterly data for the period 1995:1-1999:4. Empirical findings exhibit that both variables are co integrated and fiscal negativity grounds for negative balance of current accounts.

\subsection{Theoretical Basis for Twin Deficit}

In the literature of economics there are two main approaches which are used to explore a connection among the fiscal deficit and current account deficit. One is known as Ricardian 
equivalence hypothesis and other is Keynesian conventional proposition. These both approaches are inversed to each other.

The Ricardian equivalence, the first approach denies that there is not any relationship among both deficits. Both terms are not interrelated to each other, because people think rationally, they know that increase in taxes is not on permanent basis it is just for short time period. That is why they save the money which is received due to reduction in taxes, for the payment of higher taxes imposed by the government in future. There would not be effect on national savings. So, there would be effect of budget deficit on current account deficit (Thomas \& Abderrezak, 1988).

On the opposite side of Ricardian equivalence hypothesis (REH), the Keynesian economic theory assures the existence of long run positive relation among two of deficits. Particularly, the swot of both deficit hypotheses assures that negative fiscal account balance cause for negativity in current accounts. Similarly the surplus in budget account balance leads a proficiency in current accounts. Due to the budget deficit the government becomes borrower (Alkaswani; 2002).

Economic reasoning of affiliation among fiscal-current deficit can be found by the identity equation of national income.

$Y=C+I+G+\left(X_{E}-M_{P}\right)$

Here $\mathrm{Y}$ representing national income, $\mathrm{C}$ denotes consumption by the private sector, I represents real investment spending in the economic sector of country as some spending on infrastructure, equipment and plants etc., $\mathrm{G}$ shows the spending by the government for the purchase of goods and services at final shape. $\mathrm{X}$ is exports of goods and services, while $\mathrm{M}$ stands for the imports of different commodities and services. Current account can be expressed in the following terms.

$$
C A=\left(X_{E}-M_{P}\right)+F_{T}
$$

Here $F_{T}$ denotes net income and transfer flows.

While in addition to goods and services account balance, the income received from abroad, paid to abroad and unilateral transfers are also included in current accounts. So, here just for the sake of simplicity we suppose that net income received from abroad and unilateral transfers is not a big element in current accounts. However, it is worthy to mention that if a country has a large foreign debt and a high debt service payment, so of the income paid abroad by that country should be a big negative element.

The size and direction of foreign borrowings is shown by current accounts. When imports of country exceed from its exports, it leads to the current account deficit. This is financed by foreign borrowing (international institutions, foreign government) or by the domestic private sector. Private sector firms may borrow by selling land, equity and some other physical assets. So, the state having current account deficit must increase its own net foreign debt or by taking 
down its foreign wealth through the deficit amount. The country having current account deficit is importing the consumption at present and/or investment (if the goods of investment are imported) and is exporting consumption of future and/or investment spending.

In accordance of national income identity, in open economy national savings equal:

$$
S=I+C A
$$

Or we can write the above expression alternatively as below:

$$
S=Y-C-G+C A
$$

In this expression $(Y-C-G)=I$ is the investment function.

It is most important to see national savings closely and differentiate among the decision for savings made by the government sector and also the decision of private sector. So, we have;

$$
S=S_{P v t}+S_{G v t}
$$

Here in equation (5) $S_{P v t}$ is to as the part of disposable income $Y_{d p}$ which can be saved rather to consume. Generally we have;

$$
S_{P v t}=Y_{d p}-C=(Y-T)-C=Y-T-C
$$

In this above expression, $\mathrm{T}$ denotes the tax collection by the government. Government savings are the difference among expenditures made by government and revenues collected by the government, which is in form of government purchases $(\mathrm{G})$, and also the government transfers $\left(R_{T}\right)$, mathematical function is expressed as;

$$
S_{G v t}=T-G-R_{T}=T-G-R_{T}
$$

Now, we can write the equation (5) as follows;

$$
S=S_{P v t}+S_{G v t}=(Y-T-C)+\left(T-G-R_{T}\right)=I+C A
$$

Now to analyse the effect of government savings in an open economy (exports and imports oriented economy), we can write identity (8) as;

$$
S_{P v t}=I+C A-S_{G v t}=I+C A-\left(T-G-R_{T}\right)
$$

In alternative form it can also be written as follows;

$$
C A=S_{P v t}-I-\left(G+R_{T}-T\right)
$$

Here the identity $\left(G+R_{T}-T\right)$ consolidates the public sector, budget deficit (BDF) that is, as savings by the government preceded by the negative sign. Deficit of government measures the 
volume at which the government is borrowing to cover its expenditures. Identity (9) shows the private savings of country take three different forms; investment made in domestic capital (I), wealth purchases from foreigners by domestic government (CA), and purchase made by domestic government newly issued $\operatorname{debt}\left(G+R_{T}-T\right)$.

Examining the macroeconomic identity (equation 10), we can see that two different cases are possible. If we suppose that the difference between investment (I) and private savings ( $\left.\mathrm{S}_{\mathrm{Pvt}}\right)$ is stable over time, then the fluctuations in public sector deficit will also be completely translated to current account and the twin deficit hypothesis exists. The public sector economy consists of whole government (central and local) and also non-financial public sector enterprises (the state enterprises like as railways, air ports, and some other nationalized industries).

On the other hand, an extreme case is known as Ricardian equivalence hypothesis, which supposed that changes in fiscal deficit are fully offset through changes in savings (S). Ricardian equivalence hypothesis can be explained as a reduction in taxes does not affect the life time wealth of households, because in future taxes may go up to compensate that future increase in taxes with this present decrease. So, at present private savings will increase when taxes reduced or in accordance budget deficit rise. The households will save their income received from tax cut in response to pay for the increase in future taxes. So, budget deficit would not cause for current account deficit.

\subsection{Facts and Figures with respect to Pakistan}

This portion is related to empirical investigations of both of deficits hypothesis for Pakistan. The time series annual data is used over the period of 1990-2010. The data is collected from website of World Bank data bank.

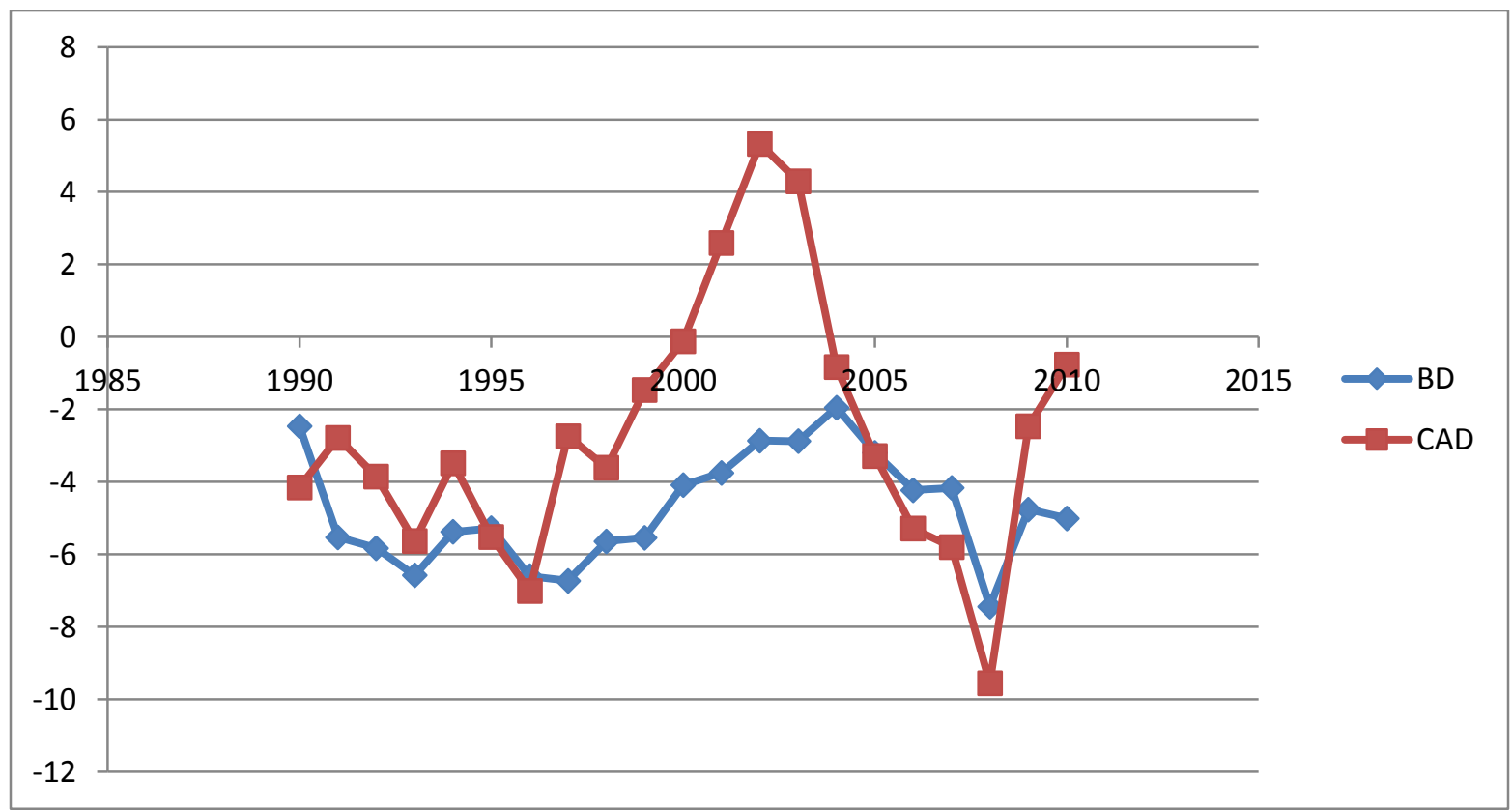

Figure 1: budget deficit and current account deficit in Pakistan

SIJMB $P$ - ISSN: 2313-1217 E-ISSN: 2410-1885 @ 2015 Sukkur Institute of Business Administration V.2, No.1| Apr 15 
Data is as the percentage of GDP i.e. BD/GDP and CAD/GDP. Most of the time series of current accounts have witnessed deficits and in minute years show a surplus balance. Overall it represents enormous fluctuations during the study period. At beginning of the sample period, current account deficit during the 1990 was -4.15 percent of GDP, after that in 1996 reaches at the lowest value of 7 percent. At the initial stage of $21^{\text {st }}$ century in 2001, 2002 and 2003 current accounts deficits were converted into surplus balance as 2, 5 and 4 percent respectively. In 2008 current account was again converted into deficit balance and reach to peak value of -9.55 percent. It was the time period of world financial crisis.

As for as the budget deficit is concerned, it also represents huge fluctuations during the sample period. Throughout the study period, budget deficit reports negative balance. At the starting time budget deficit balance was -2.46 percent of GDP, in 2008 faces the highest value of 7.44 percent. It is concluded that higher budget deficit was recorded in 2008. In the same year current account balance also has the largest negative value -9.55 percent. So, according to these observations both the variables are interrelated to each other.

\section{Data and Methodology}

Theoretical background of the issue which discussion gives strong possible connection among the variables. The empirical validity of twin deficit becomes an important subject. By trailing the modern literature, we inspect that hypotheses is tested with the help of different econometric techniques. At first step, we checked out the stationarity of the variables through application of ADF (Augmented Dickey Fuller) test. At the second stage, we apply Granger Causality test and then apply OLS (Ordinary Least Square).

\section{Econometric Methodology}

\section{Unit Root Estimation.}

The test to check the stationarity of the variables which becomes most popular from many previous years is Unit root test. ADF test is also one of most popular Unit root test to check the stationarity of variables. So, the $\mathrm{Y}$ the time series is supposed to integrate by order (d). To check out the prescribed stat of stationarity, we have applied the Augmented Dickey Fuller test. The subsequent equation of regression is to be supposed.

$$
\Delta Y_{t}=\alpha_{0}+\alpha_{1} t+\alpha_{2} Y_{t-1} \sum_{j=2}^{q} \alpha_{j} \Delta Y_{t-j+1}+\varepsilon_{t}
$$

Here $\mathrm{Y}$ is representing a macroeconomic variable with time trend $t$, while $\varepsilon_{t}$ is expressed as a disturbance term.

\section{Cointegration test}

Examination of cointegration test allows checking the association of long run equilibrium amid the variable in the long run, which becomes stationary at first difference. If the entire variables used in the study are stationary, we will investigate the test of cointegration. To test out the long run equilibrium connection stuck between subjects, the implication of different 
cointegration statistics are made feasible. Two tests of statistics are used for the examination of cointegration which was suggested by (Johansen 1990); and by (Johansen and Juselius 1990), which are known as trace test and the maximum Eigenvalue test. Trace test is used to check the null hypothesis $\left(\mathrm{H}_{0}\right)$, we can examine the trace test as follows.

$$
\lambda_{\text {trace }}(r)=-T \sum_{i=r+1}^{p} \ln \left(1-\hat{\lambda}_{i}\right)
$$

Here " $\hat{\lambda}_{r+1} \ldots \ldots \ldots . . . \hat{\lambda}_{n}$ " is representing the lowest value eigenvector (P-r). So, null hypothesis expressed strength of various cointegration are equal or less then (r), in opposite of common unrestricted alternative which is being in excess then ( $r$ ).

The other test of statistics can be performed as below:

$$
\lambda_{\max }(r, r+1)=-T \ln \left(1-\hat{\lambda}_{r+1}\right)
$$

The above expression has laid foundation on maximum Eigenvalue. It's only concerned to check null hypothesis which is (r) for vector, cointegrating in comparative to alternative which is $(\mathrm{r}+1)$.

\section{Impulse Response}

Impulse Response function is the method engaged for the measurement of unpredicted variations in a variable say $\mathrm{X}$ (impulse) in a time trend $t$ forecasting its consequences on the variable $\mathrm{Y}$ during a time trend $t, t+1, t+2, t+3+\ldots \ldots+t+\mathrm{n}$ etc (response). This function describes the outcome of variable $\mathrm{X}$ on the variable $\mathrm{Y}$ other anyone else. When there is the existence of only two variables in the study, say $\mathrm{X}_{t}$ and $\mathrm{Y}_{t}$ the type of impulse response function would be as below.

$$
\begin{gathered}
Y_{t}=\alpha_{1}+\varepsilon_{Y, t}+\eta_{1} \varepsilon_{Y, t-1}+\eta_{2} \varepsilon_{Y, t-2} \ldots \ldots \ldots \eta_{i} \varepsilon_{Y, t-i} \\
X_{t}=\alpha_{2} \varepsilon_{X, t}+\varphi_{1} \varepsilon_{X, t-1}+\varphi_{2} \varepsilon_{X, t-2} \ldots \ldots \ldots . \varphi_{i} \varepsilon_{X, t-i}
\end{gathered}
$$

These above mentioned equations state that how an endogenous variable cause to exogenous variable $(\mathrm{X} t$ or $\mathrm{Y} t)$.

\section{Granger Causality Test}

Granger Causality is a term for particular conception of the causality in analysis of the time series. If couple of the series interrelated to each other than the Granger Causality must have to exist at least from one way, which shows the influence track amid the series. Here, if lagged or current terms of the variable which is time series, consider $X_{t}$, conclude that one other variable of time series, supposed $Y_{t}$, then there would be the existence of Granger Causality connection stuck between the variables of $X_{t}$ and $Y_{t}$. 


$$
\begin{gathered}
\Delta Y_{t}=\eta_{1}+\sum_{i=1}^{n} \alpha_{i} \Delta X_{t-i}+\sum_{j=1}^{n} \beta_{j} \Delta Y_{t-j}+U_{1 t} \\
\Delta X_{t}=\eta_{2} \sum_{i=1}^{n} \lambda_{i} \Delta X_{t-i}+\sum_{j=1}^{n} \delta_{j} \Delta Y_{t-j}+U_{2 t}
\end{gathered}
$$

Here in the above $U_{1}$ and $U_{2}$ represents the disturbance terms which are not interrelated to each other, the constant terms are shown as $\eta_{1}$ and $\eta_{2}$ and $\delta, \beta_{j}, \alpha_{i}$ and $\lambda_{i}$ are the coefficients.

Let $\mathrm{X}$ correspond to the budget deficit and the variable $\mathrm{Y}$ symbolize current accounts deficit. Then there would be four hypothesis of Granger Causality test: negative balance of budgetary accounts correspond to current account negativity, deficit of current accounts lead to fiscal deficit, bi-directional causality exist among both variables, both deficits are not causally interrelated.

\section{Empirical Results}

To break out the structural trends in data, we applied unit root test under ADF (Augmented Dickey Fuller) method. The results of subject's variable divert us toward order of 1(1). The structural trends in the fiscal deficit time series data set break out under Augmented Dickey Fuller test at $1^{\text {st }}$ difference. So, the order of integration for fiscal deficit lead us to $I(1)$, on the other hand Current account deficit also becomes stationary at $1^{\text {st }}$ difference at $5 \%$ level of significance and leads us to $I(1)$ order of integration. Hence, according to the results we move towards further on--trace test.

Table 1: Unit Root Test Results

\begin{tabular}{|l|l|l|l|l|l|}
\hline & \multicolumn{2}{|l|}{$\begin{array}{l}\text { Augmented Dickey } \\
\text { Fuller Test } \\
\text { Level }\end{array}$} & $\begin{array}{l}\text { Augmented } \\
\text { Fuller Test } \\
\text { 1st Difference }\end{array}$ & Dickey & Conclusion \\
\hline Variables & $\begin{array}{l}\text { Without } \\
\text { Trend }\end{array}$ & $\begin{array}{l}\text { With } \\
\text { Trend }\end{array}$ & $\begin{array}{l}\text { Without } \\
\text { Trend }\end{array}$ & $\begin{array}{l}\text { With } \\
\text { Trend }\end{array}$ & \\
\hline Budget deficit & 2.58 & 2.90 & $5.90^{*}$ & $5.64^{*}$ & $I(1)$ \\
\hline $\begin{array}{l}\text { Current account } \\
\text { deficit }\end{array}$ & 1.81 & 3.42 & $3.97^{*}$ & $3.84^{*}$ & $I(1)$ \\
\hline
\end{tabular}

Note: 1\%, 5\% and 10\% critical values for Augmented Dickey Fuller Test (ADF) level are $3.80,3.02$, and 2.65 for without trend, while $1 \%, 5 \%$ and $10 \%$ critical values with trend are 4.49, 3.65, and 3.26 respectively. $1 \%, 5 \%$ and 10\% critical values for Augmented Dickey Fuller Test $(A D F)$ on $1^{\text {st }}$ difference without trend are 3.83, 3.02 and 2.65 while 1\%, 5\% and $10 \%$ critical values with trend are 4.53, 3.67 and 3.27 respectively 
Table 2: Cointegration Test Result

\begin{tabular}{|l|l|l|l|l|}
\hline \multicolumn{5}{|c|}{ Unrestricted Co-integration Rank Test (Trace) } \\
\hline $\mathrm{H}_{0}$ & $\mathrm{H}_{1}$ & Trace Statistics & 0.05 Critical Value & Prob. \\
\hline $\mathrm{r}=0^{*}$ & $\mathrm{r} \geq 1$ & 141.9786 & 95.75366 & 0.0000 \\
\hline $\mathrm{r} \leq 1^{*}$ & $\mathrm{r} \geq 2$ & 82.89489 & 69.81889 & 0.0032 \\
\hline $\mathrm{r} \leq 2$ & $\mathrm{r} \geq 3$ & 45.08015 & 47.85613 & 0.0891 \\
\hline
\end{tabular}

\begin{tabular}{|l|l|l|l|l|}
\hline \multicolumn{5}{|c|}{ Unrestricted Co-integration Rank Test (Maximum Eigen value) } \\
\hline $\mathrm{H}_{0}$ & $\mathrm{H}_{1}$ & Max-Eigen Statistics & 0.05 Critical Value & Prob. \\
\hline $\mathrm{r}=0^{*}$ & $\mathrm{r} \geq 1$ & 59.08367 & 40.07757 & 0.0001 \\
\hline $\mathrm{r} \leq 1^{*}$ & $\mathrm{r} \geq 2$ & 37.81475 & 33.87687 & 0.0161 \\
\hline $\mathrm{r} \leq 2$ & $\mathrm{r} \geq 3$ & 26.66635 & 27.58434 & 0.0652 \\
\hline \multicolumn{4}{|c}{ Denotes rejection of the null hypothesis at the 0.05 level }
\end{tabular}

The consequences of Johansen cointegration demonstrate that there are numerous equilibrium associations amongst the variables. In Unrestricted Cointegration approximately two dissimilar kind of cointegration affiliation exist amid variables i.e. Budget deficit and current account deficit at $0.05 \%$ level of significance and in Maximum Eigenvalue the outcome represents that there is the existence of at least two types of integration relationship amongst the variables.

Table 4: Granger Causality Test Result

\begin{tabular}{|c|c|c|}
\hline Null Hypothesis & F-Statistic & Prob \\
\hline CAD does not Granger Cause BD & 4.73100 & 0.0269 \\
\hline BD does not Granger Cause CAD & 1.49321 & 0.2583 \\
\hline
\end{tabular}

To interpret Pairwise Granger causality test with lags specification of two, we build up hypothesis as:

$\mathrm{H}_{0}=$ Current account does not Granger cause Budget deficit vice versa.

$\mathrm{H}_{\mathrm{a}}=$ Current account do cause budget deficit vice versa.

The rule of thumb is that if the F-Stat under Granger causality trace test is greater than 4 and the on other side Probability value is less than 0.05 , then we will accept alternative hypothesis and dip down to null hypothesis. Here results illustrate that current account deficit is causing (CAD has relation with BD) budget/fiscal deficit. In reaction budget deficit does not cause current accounts balance. So, results of Granger Causality test express that there is unidirectional connection amid variables. The economic interpretation behind it is that current 
account deficit cause deficit in budget, because deficit in current account creates shortage of funds to pay for imports and creates budget deficit.

Table 3: Long Run and Short Run

\begin{tabular}{|l|l|l|l|l|l|l|l|}
\hline \multicolumn{9}{|c|}{ Long Run Analysis } \\
\hline Dependant variable is bd & \multicolumn{2}{|l|}{ Dependant variable: cad } \\
\hline Variable & Coefficient & t-stat & Probability & Variable & Coeff & t-stat & prob \\
\hline C & -4.54 & -7.189 & 0.000 & C & -0.03 & -0.035 & 0.97 \\
\hline Cad & 0.47 & 3.14 & 0.0036 & bd & 0.50 & 3.14 & 0.0036 \\
\hline Ad R & 0.23 & D.W Stat & 1.42 & Ad R & 0.23 & D.W & 1.05 \\
\hline Short Run Analysis \\
\hline dependant variable: bd \\
\hline C & 0.11 & .027 & 0.7859 & C & 0.06 & 1.12 & 0.951 \\
\hline Dcad & 0.21 & 1.27 & 0.2122 & Dbd & 0.51 & 0.174 & 0.006 \\
\hline Ecm & -0.72 & -4.33 & 0.0002 & ecm & -0.10 & 0.193 & 0.584 \\
\hline Ad R $^{2}$ & 0.39 & D.W Stat & 2.11 & Ad R $^{2}$ & 0.22 & D.W & 1.16 \\
\hline
\end{tabular}

Table 3 shows the results of short run and long run analysis of the model. Both the variables have positive sign which means that deficit in current account leads to deficit in budget and vice versa in the long run. While the magnitude of the coefficient is also equal like $47 \%$ and $50 \%$. The short run analysis also depicts very interesting results. The model which have budget deficit as dependant variable shows that disequilibrium in the previous year is corrected $72 \%$ in the current period. On the other hand, the model which takes current account deficit as dependant variable shows that only $10 \%$ disequilibrium of the previous year is corrected in the current period.

Figure 1: Impulse Response Function

Response to Cholesky One S.D. Innovations \pm 2 S.E.

Response of BD to $B D$

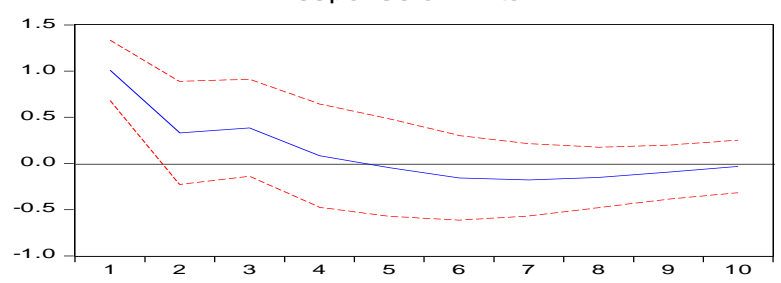

Response of CAD to BD

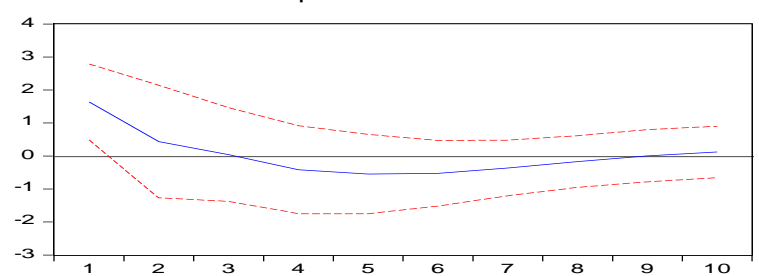

Response of BD to CAD

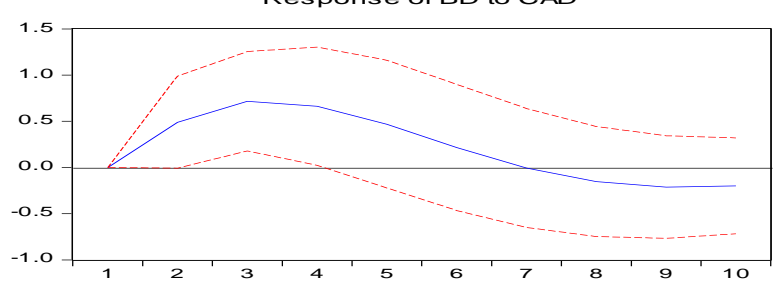

Response of CAD to CAD

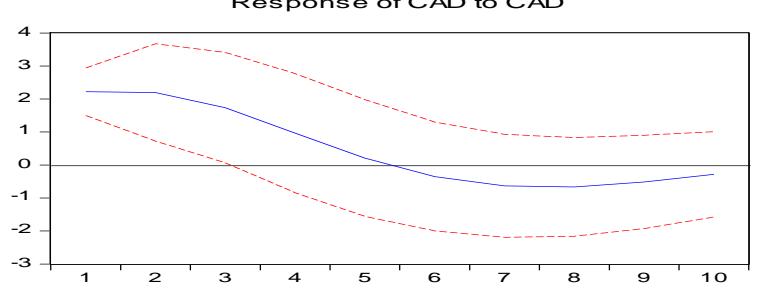

Impulse response function is an additional method to diagnose connection amongst budgetary deficit balance and negative balance of current account, as predominately it clarifies that how 
while giving a shock to one variable would influence to other variable. Now we have checked the impulse response function under Response to Cholesky S.D Innovations.

First we check the response of CAD to CAD itself, while giving a shock to CAD to its own lag is positive until reaching $4^{\text {th }}$ lag up to and after that becomes negative. Figure-2 representing response of $\mathrm{BD}$ to $\mathrm{CAD}$, when shock to $\mathrm{CAD}$ then representing a positive association among both variables up to $6.5^{\text {th }}$ lag. In comparative in figure-3 we test the responses of $\mathrm{CAD}$ to $\mathrm{BD}$ which is reporting positive results up to $2.5^{\text {th }} \mathrm{lag}$. In the last figure CAD to CAD is presented by which we conclude that there is existence of bi-directional connection amongst variables of interest.

\section{Conclusion and Policy Recommendations}

This study examines the long-term equilibrium association/causality amid current account deficit and budget deficit in case of Pakistan's economy. Key purposes of these examinations are to investigate the existence of twin deficits hypothesis. The data in the study is used over the period of 1970-2010. We investigate the results through a process of unit root test, cointegration analysis, impulse response function and Granger causality test. Empirical outcomes demonstrate that there is existence of twin deficits in Pakistan. It is concluded that current account deficit Granger cause to budget deficit. On the other hand, budget balance does not cause to current account deficit. So, there is uni-directional causality in Pakistani data.

Basically, Pakistan is a developing country, not developed one, with an agrarian economy and abundance of labour force. Pakistan is not proficient in technological progress as compared to developed nations. Due to illiteracy and political instability investment projects are not working properly. So output level is going to decline, in diverse dimension. Population is increasing rapidly which is causing higher demand for goods and services, which are not being produced enough domestically. For the fulfilment of these requirements, we import goods and services. 


\section{References:}

Akhter, A. (2010). Twin deficit problem in developing countries; case study of Pakistan. Thesis of M.Phill; Allama Iqbal open University, 01-102.

Alkswani, M. A. (2002), "The Twin Deficits Phenomenon in Petroleum Economy: Evidence from Saudi Arabia”, Discussion Papers of Department of Economics, King Saud University.

Azgun, S., \& Ozdemir, T. (2008). Current Accounts Deficits Sustainability: Iimplications Intertemporal Foreign Borrowing Constraints for Pakistan. Trakia Journal of Sciences , 39.

Bagheri, F., \& Keshtkaran, S. (2012). Twin Deficits and Feldstein-Horioka Puzzle in the Case Iran. Journal of Social and Development Sciences , 167-171.

Baharumshah, A. Z., Ismail, H., \& Lau, E. (2009). Twin Deficits Hypothesis and Capital Mobility: The ASEAN-5 Perspective. Jurnal Pengurusan , 15-32.

Edwards, S. (2001), “Does Current Account Matter?”, NBERWorking Papers, National Bureau of Economic Research, 8275.

Engle, R.F. and C.W.J. Granger (1987), Cointegration and Error -Correction: Representation, Estimation, and Testing, Econometrica, 55(2), 251-276.

Ibrahim, S. B. and Kumah, F.Y. (1996), "Co-movements in Budget Deficits, Money, Interest Rate, Exchange Rate and the Current Account Balance: Some EmpiricalEvidence”, Applied Economics, 28, 117-130.

Johansen, S. (1991), "Estimation and Hypothesis Testing of Cointegration Vectors in Gaussian Vector Autoregressive Models”, Econometrica, 59 (6), 1551 -1580.

Johansen, S. and Juselius, K. (1990), "Maximum Likelihood Estimation and Inference on Cointegration with Applications to the Demand for Money", Oxford Bulletin of Economics and Statistics, 52, 169-210.

Lam, N. X. (2012). Twin Deficits Hypothesis and Feldstein-Horioka. International Research Journal of Finance and Economics , 169-178.

Lau, E. and Baharumshah, A. Z. (2006), "Twin Deficits Hypothesis in SEACEN Countries: A Panel Data Analysis of Relationships between Public Budget and Current Account Deficits ”, Applied Econometrics and International Development, 6 (2), 213-226.

Mann, C. L. (2002), "Perspectives on the U.S. Current Account Deficit and Sustainability”, Journal of Economic Perspectives, 16 (3), 131-152. 
Merza, E., Alawin, M., \& Bashayreh, A. (2012). The Relationship between Current Account and Government Budget Balance: The Case of Kuwait. International Journal of Humanities and Social Science, 168-177.

Mukhtar, T., Zakaria, M., \& Ahmed, M. (2007). An Empirical Investigation For The Twin Deficits Hypothesis in Pakistan. Journal of Economic Cooperation, 63-80.

Nazier, H., \& Essam, M. (2012). Empirical Investigation of Twin Deficits Hypothesis in Egypt. Middle Eastern Finance and Economics , 45-58.

Normandin, M. (1999), "Budget Deficit Persistence and the Twin Deficits Hypothesis", Journal of International Economics, 49 (1), 171-193.

Saeed, S., \& Khan, M. A. (2012). Ricardian Equivalence Hypothesis and Budgetary Deficits: The Case of Pakistan. Interdisciplinary Journal of Contemporary Research in Business, 1432-1446.

Saeed, S., \& Khan, M. A. (2012). Twin Deficits Hypothesis: The Case of Pakistan. PartI: Natural \& Applied Sciences , 155-162.

Thomas, Lloyd and Abderrezak, Ali. (1988) "Anticipated Future Budget Deficits and the Term Structure of Interest Rates," Southern Economic Journal, Vol. 55 Issue 1, pp. 150161.

Vyshnyak, O. (2000). Twin Deficit Hypothesis: The Case of Ukraine. Master of Arts Thesis; National University kyiv Mohyla Academy, 1-54.

Yanik, Y. (2006). The Twin Deficit Hypothesis: An Empirical Investigation. A Thesis of Master in Economics; submitted graduate school of social sciences , 01-62.

Zamanzadeh, A., \& Mehrara, M. (2011). Testing Twin Deficits Hypothesis in Iran. Interdisciplinary Journal of Research in Business , 7-11. 